\title{
Peroxidative Activity in Patients with Skin Basal Cell Carcinoma
}

\author{
Hoda Rahmani ${ }^{{ }^{*}}$, Mohsen Korani ${ }^{2}$, Mohamad Reza Sarasgani ${ }^{2}$, Hamid Reza Fathi ${ }^{3}$, \\ Pedram N. Mohamadpoor ${ }^{1}$ \\ ${ }^{1}$ Department of Dermatology, Tehran University of Medical Sciences, Tehran, Iran; ${ }^{2}$ Department of Biochemistry, Tehran University \\ of Medical Sciences, Tehran, Iran; ${ }^{3}$ Department of Plastic, Reconstructive and Aesthetic Surgery, Tehran University of Medical Sci- \\ ences, Tehran, Iran. \\ Email: *rahmanihoda10@gmail.com
}

Received May $18^{\text {th }}, 2013$; revised June 20 ${ }^{\text {th }}, 2013$; accepted June $29^{\text {th }}, 2013$

Copyright (C) 2013 Hoda Rahmani et al. This is an open access article distributed under the Creative Commons Attribution License, which permits unrestricted use, distribution, and reproduction in any medium, provided the original work is properly cited.

\begin{abstract}
Oxidative status assessment is an initial step in tumor related studies. To the best of our knowledge, this is the first study considering oxidative activity of both serum and tissue specimens in human basal cell carcinoma (BCC), which is the most common tumor in the world. Concentration of Malondialdehide (MDA) in human basal cell carcinoma (BCC) and individually matched normal skin tissue were examined with spectrophotometery method. Fresh normal and cancerous skin paired tissue was obtained from 60 patients who underwent curative BCC resection at one center in Tehran (Razi hospital). Serum Concentration of Malondialdehide (MDA) in these patients and 55 normal subjects were also measured. MDA level in cancerous tissue of patients with skin BCC $(1.0 \pm 0.14 \mathrm{ng} / \mathrm{g})$ was significantly $(\mathrm{p}=0.001)$ higher than normal neighboring skin tissue $(0.3 \pm 0.07 \mathrm{ng} / \mathrm{g})$. A remarkable (Not significant, $\mathrm{P}=0.18$ ) increase was found in the serum MDA level in patients with skin BCC $(8.0 \pm 2.3 \mathrm{ng} / \mathrm{ml})$ in comparison with the control subjects $(7.3$ $\pm 2.9 \mathrm{ng} / \mathrm{ml})$. A significant positive correlation $(\mathrm{r}=0.276, \mathrm{p}=0.03)$ was found between Serum MDA and skin tissue MDA for non-affected skin tissue (normal neighboring skin), whereas no significant correlation ( $>0.05$ ) was found for cancerous tissue. Cut-point of $5.2 \mathrm{ng} / \mathrm{ml}$ of serum MDA concentration showed a screening sensitivity of $95 \%$. There is an active oxidative process in BCC lesions. Serum MDA concentration can be used either as a screening test or a predictor for tissue MDA concentration.
\end{abstract}

Keywords: Malondialdehyde; Skin Cancer; Screening; Oxidative Stress; Basal Cell Carcinoma

\section{Introduction}

Basal cell carcinoma (BCC) is the most common tumor in light skin people [1]. It rarely metastasize but its frequent recurrences and local invasions make it highly morbid [2]. In almost all patients, the recommended treatment is surgery $[3,4]$, therefore $\mathrm{BCC}$ contributes a large economic burden in susceptible countries $[5,6]$.

Annual incidence rate for BCC was estimated 60,587 in 2004 in Canada which was predicted to reach 157,711 until 2031 [6]. As what has been mentioned by American Cancer Society, BCC incidence doubles every 25 years. This progressive ascending incidence rate of $\mathrm{BCC}$ may be due to its unknown exact physiopathology, making it hard to be protected. Studies on oxidative status of this tumor may help to discover more details about its patho-

${ }^{*}$ Corresponding author. genesis. Oxidation is a process which produces free radicals from cellular structures. Peroxidation is an oxidative process of unsaturated fatty acids (UFAs), resulting in creation of free radicals and carcinogenic metabolites such as malondialdehyde (MDA). The latter is the best indicator for peroxidative activity $[7,8]$. MDA level has been estimated in many tumors but to our knowledge, there is no study which considered both serum and tissue MDA levels exclusively in patients with skin BCC.

In this study, we aimed at proving a high peroxidative activity in BCC skin lesions which predicts the probable response of the tumor to local or systemic antioxidants in at-risk patients. It was also displayed that the serum MDA level is a significant predictor for tissue MDA of non-affected skin in these patients. Furthermore, serum MDA level tends to be a screening test to detect the population at higher risk for developing skin BCC. 


\section{Materials \& Methods}

\subsection{Subjects}

The study was approved by Tehran university research ethics committee and followed the tenets of the declaration of Helsinki. An informed consent was obtained from all patients. It was performed on the patients who were admitted in surgical ward in Razi hospital, the biggest specialized skin center in Iran for BCC resection, formerly diagnosed by a specialized dermatopathologist. The patients older than 50 years with new BCC lesions of the skin of the face or scalp which were decided to be resected and reconstructed by flap surgery were included. The exclusion criteria were the unwilling patient to participate in the study, congenital or acquired immunodeficiency states, presence of other tumors in the skin or the other organs, patients with positive serology for viral hepatitis and patients using immunosuppressive medications which had been used during the last two years for a minimum period of 3 weeks. This study was conducted in 60 persons (42 men, 18 women, mean age $62.9 \pm 5.9$ years) with affected skin by BCC who were supposed as the case group and 55 persons ( 33 men, 22 women, mean age $60.2 \pm 8.0$ years) with the same exclusion criteria but without $\mathrm{BCC}$ lesions as the control group for serum MDA. The latter group consisted of the patients who referred to the laboratory for the reasons other than malignancies. The control group for tissue MDA of BCC lesions was the excessive non-affected skin which was derived from the flap. The tissue specimens were taken from the sites which were neither ulcerated nor infected grossly.

\subsection{Laboratory Analysis}

In order to estimate the serum MDA concentration, $2 \mathrm{~mL}$ of blood were obtained after a whole night fasting of about 10 hours. The blood samples were centrifuged at $3000 \mathrm{rpm}$ and the resulting serums were isolated and stored at $-70^{\circ} \mathrm{C}$. The skin specimens were washed well with cold normal saline $0.9 \%$, immediately after resection to become completely free from blood. The fatty subcutaneous tissue was cut out and the remained tissue, consisting epidermis and dermis, were fresh frozen in liquid nitrogen and stored at $-70^{\circ} \mathrm{C}$ for further analysis. In order to tissue analysis by spectrophotometery method, it was mandatory to transform the skin specimens from the solid phase into a liquid phase. For this purpose, the freezed tissue samples were weighed; then were homogenized (1:2) in Tris-HCl buffer (20 mM, PH: 7.4). The resulted liquid samples were ready to be analyzed by spectrophotometery method. The peroxidative activity is easily affected by environmental factors; therefore a rapid procedure for preparing and analysis of the specimens is preferred. The spectrophotometery is a time-saving method for this purpose in addition to be quantitative and easy to perform. We used the method which was first described in 1991 and Pampanin et al. were also used it in their study on digestive glands [9]. Specimens (serum and homogenized tissue), were centrifuged $(10,000 \mathrm{~g})$ at the temperature of $4^{\circ} \mathrm{C}$ for 20 minutes. $100 \mu \mathrm{L}$ of the separated supernatant was incubated with $900 \mu \mathrm{L}$ of NMPI solution (contains $650 \mu \mathrm{L}$ of $10.3 \mathrm{mM} \mathrm{N}$-Methyl-2phenylindol, $100 \mu \mathrm{L}$ distilled water, and $150 \mu \mathrm{L}$ of $37 \%$ $\mathrm{HCl}$ ), for 60 minutes at $45^{\circ} \mathrm{C}$. After being incubated with NMPI, MDA content of the samples was turned to a chromophore agent with absorbance at $586 \mathrm{~nm}$. In order to prepare a calibration curve, we used TMOP (tetramethoxypropane) as the standard. This agent is changed into MDA after hydrolysis. Tissue and serum MDA concentrations were described as $\mathrm{ng} / \mathrm{g}$ and $\mathrm{ng} / \mathrm{ml}$ respectively. MDA concentrations were calculated by following formulation: $\mathrm{MDA}=[(\mathrm{ODs}-\mathrm{b}) / \mathrm{a}) \mathrm{f}]$; $\mathrm{a}$ and $\mathrm{b}$ quantities were derived from the standard curve, OD represented the optical density of the samples and $\mathrm{f}$ was the dilution factor.

\subsection{Statistical Analysis}

Results were compared with independent sample $\mathrm{T}$ test in SPSS 16.0. P-values $<0.05$ were described statistically significant. Results related to each pathologic type of BCC were analyzed by one-way ANOVA. In order to detect the correlation between serum MDA and tissue MDA, we used the simple linear regression test and the sensitivity and specificity of the results were defined by receiver operating characteristic (ROC) analysis.

\section{Results}

The general characteristics of this population are shown in Table 1. As shown in Figure 1(a) mean concentration of tissue MDA in the cancerous skin $(1 \pm 0.14 \mathrm{ng} / \mathrm{g})$ was significantly $(\mathrm{p}<0.001)$ more than MDA concentration of non-affected skin $(0.3 \pm 0.07 \mathrm{ng} / \mathrm{g})$, Although MDA concentration was not significantly different among four microscopic types of BCC (solid, sclerotic, basosquamous and undetermined) as described by dermatopathology (Figure 1(b)). A remarkable (Not significant, $P=0.18$ )

Table 1. Baseline data of the participants and their demographic characteristics.

\begin{tabular}{cccc}
\hline Variables & Controls $(\mathrm{n}=55)$ & Patients $(\mathrm{n}=60)$ & $\mathrm{P}$ \\
\hline Age (years) & $60.2 \pm 8.0$ & $62.7 \pm 5.9$ & $\mathrm{NS}$ \\
Smoking (\%) & 9.0 & 11.6 & $\mathrm{NS}$ \\
Hypertention (\%) & 52.7 & 41.6 & $\mathrm{NS}$ \\
Hyperlipidemia (\%) & 38 & 40 & NS \\
Thyroid disease (\%) & 0 & 1.6 & NS \\
Diabetes mellitus (\%) & 30 & 30 & NS \\
\hline
\end{tabular}

Values are Mean \pm SD, NS: Not Significant. 


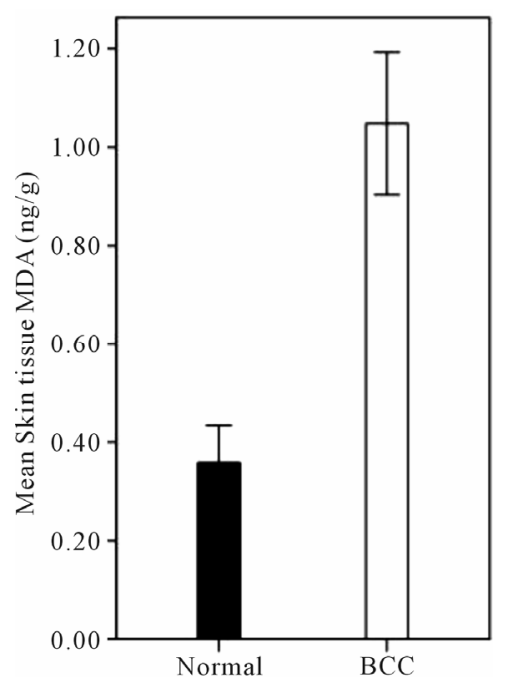

(a)

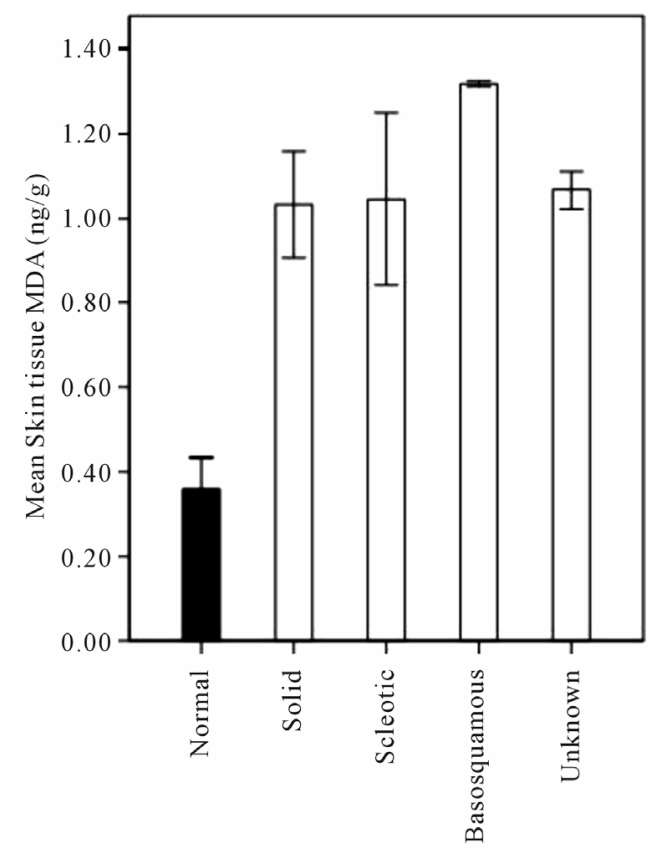

(b)

Figure 1. (a) Mean skin tissue MDA concentration (ng/g) in human BCC lesions and non-affected skin (Normal). Mean skin tissue MDA in the cancerous skin $(1 \pm 0.14 \mathrm{ng} / \mathrm{g})$ was significantly $(P<0.001)$ more than MDA concentration of non-affected skin $(0.3 \pm 0.07 \mathrm{ng} / \mathrm{g})$; (b) ANOVA analysis showed no significant difference for MDA levels among four microscopic types of BCC (solid, sclerotic, basosquamous and undetermined). Data are mean \pm SD.

increase was found in the serum MDA level (Figure 2) in patients with skin BCC $(8.0 \pm 2.3 \mathrm{ng} / \mathrm{ml})$ in comparison with the control subjects $(7.3 \pm 2.9 \mathrm{ng} / \mathrm{ml})$. As shown in Figure 3 among the patients with affected skin by $\mathrm{BCC}$, mean serum MDA was significantly correlated $(\mathrm{r}=$ $0.276, \mathrm{P}=0.03)$ with mean tissue MDA of the non-affected flap derived skin (normal), although the same cor-

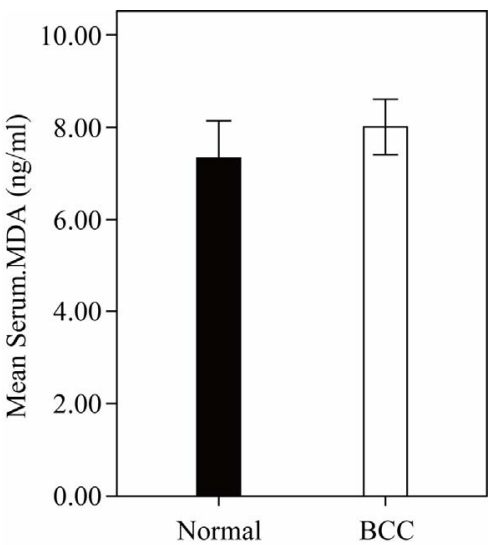

Figure 2. Mean serum MDA concentration (ng/ml) in normal subiects and patients with BCC lesions. An increase (No significant, $P=\mathbf{0 . 1 8}$ ) was found in the serum MDA level in patients with skin BCC $(8.0 \pm 2.3 \mathrm{ng} / \mathrm{ml})$ in comparison with the control subjects $(7.3 \pm 2.9 \mathrm{ng} / \mathrm{ml})$.

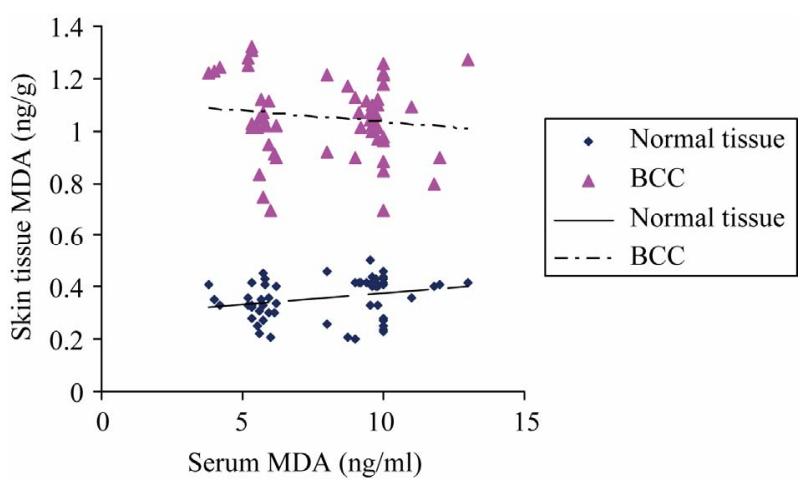

Figure 3. Correlation between serum MDA (ng/ml) and skin tissue MDA in patients with BCC lesions. among the patients with affected skin by BCC, mean serum MDA was significantly correlated $(r=0.276, P=0.03)$ with mean tissue MDA of the non-affected flap derived skin (normal), although the same correlation was not found between mean serum MDA concentration and tissue MDA in affected tissue by BCC (p > 0.05).

relation was not found between mean serum MDA concentration and tissue MDA in affected tissue by BCC (p $>0.05$ ). The validity of serum MDA concentration as a screening test was evaluated by receiver operating characteristic (ROC) analysis. The calculated area under the curve was 0.621 which was significantly different from the line $0.5(p=0.02)$. The cut-point for appropriate serum MDA concentration for screening was $5.2 \mathrm{ng} / \mathrm{ml}$ with a sensitivity of $95 \%$ and specificity of $48 \%$ (Figure 4 ).

\section{Discussion}

Peroxidation is the oxidative process, mainly of the unsaturated fatty acids (UFAs). The best indicator of peroxidative activity is the level of MDA which is one the end metabolites of this biochemical pathway $[7,8]$. This 


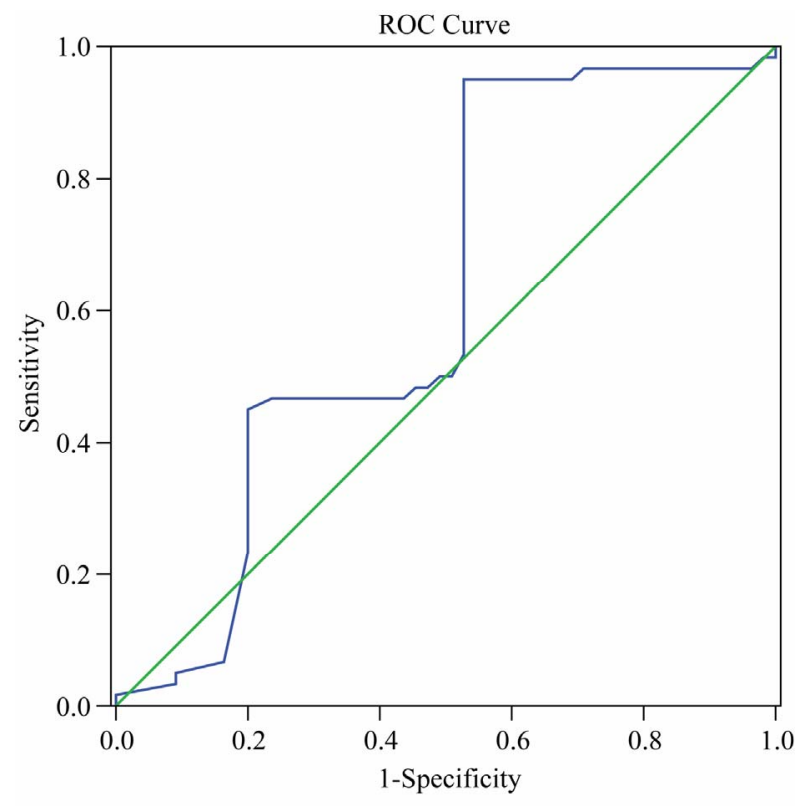

Figure 4. Evaluation of serum MDA concentration as a screening test by receiver operating characteristic (ROC) analysis. The calculated area under the curve was 0.621 which was significantly different from the line $0.5(p=0.02)$. The appropriate serum MDA concentration cut-point for screening was $5.2 \mathrm{ng} / \mathrm{ml}$ with a sensitivity of $95 \%$ and specificity of $48 \%$.

is the first study which assesses both serum and tissue peroxidation activity exclusively in human skin BCC. In our study, the serum MDA level was not increased significantly in patient with skin BCC. In contrast, Bekerecioğlu et al. in their study, showed a significant higher serum MDA level in patients with non-melanoma skin carcinomas (NMSC); both SCC or BCC [10]. Studies on SCC of oral cavity, also showed higher serum MDA levels than healthy groups $[11,12]$. In tumors of other organs, such as the liver, breast, lung, etc. the serum MDA was also significantly elevated [13-15]. In contrast to serum MDA levels in our study, it is suggested that sporadic skin BCC development is predominantly affected by exogenous etiologic factors such as radiation rather than endogenous etiologies. In our study, the tissue MDA level of the skin with BCC was significantly higher than non-affected skin tissue. In a study which considered the effect of antioxidants on photodamaged skin, vitamin E significantly decreased the tissue MDA [16]. Another study on tumor of murine liver, tissue MDA level was increased significantly after radiation and decreased significantly after antioxidant therapy with melatonin [17]. Other similar studies detected inhibitory effects of several antioxidants and even diet on incidence and progression rates of different tumors [18-21]. According to significant increase of tissue MDA in BCC skin lesions in our study, it is suggested that the use of local or systemic antioxidants may have protective effects on incidence and recurrence rates of skin BCC. In their studies, Black H.S [22] Fischer [23] Mei Qi [24] and Mackie [25] mentioned that UFAs are carcinogenic when they are exposed to ultraviolet radiation (UV) in the skin. Other studies also estimated a correlation between UV-dependent cancers and UFAs $[26,27]$. Considering that UFAs are the main targets for peroxidation, it is may be judicious to recommend less consumption of UFAs for patients at risk for developing BCC, such as a positive history of previous radiotherapy, but lacking risk factors for diabetes and cardiovascular diseases, to decrease the UFAs consumption in their diets. To detect the patients at risk for skin BCC, a laboratory screening test would be useful. For this purpose, we suggest serum MDA levels of more than $5.2 \mathrm{ng} / \mathrm{ml}$ as a cut-point to screen the at risk population for developing skin BCC to further protective health programs.

\section{Conclusion}

A high peroxidative activity in BCC skin lesions was detected which may predict the probable response of the tumor to local or systemic antioxidants in at-risk patients. It was also displayed that the serum MDA level is a significant predictor for tissue MDA of non-affected skin in these patients. Serum MDA level tends to be a screening test to detect the population at higher risk for developing skin $\mathrm{BCC}$.

\section{Acknowledgements}

This study was supported by a grant from the Tehran University of Medical Sciences. The authors wish to thank Razi Hospital for providing the samples.

\section{REFERENCES}

[1] S. J. Miller, "Aetiology and Pathogenesis of Basal Cell Carcinoma," Clinical Dermatology, Vol. 13, No. 6, 1995, pp. 527-536. doi:10.1016/0738-081X(95)00062-K

[2] C. S. Wong, R. C. Strange and J. T. Lear, "Basal Cell Carcinoma," BMJ, Vol. 327, No. 7418, 2003, pp. 794-798. doi:10.1136/bmj.327.7418.794

[3] J. Barry, S. F. Oon, R. Watson and L. Barnes, "The Management of Basal Cell Carcinomas," Irish Medical Journal, Vol. 99, No. 6, 2006, pp. 179-181.

[4] M. Dandurand, T. Petit, P. Martel and B. Guillot, "Management of Basal Cell Carcinoma in Adults Clinical Practice Guidelines," European Journal of Dermatology, Vol. 16, No. 4, 2006, pp. 394-401.

[5] N. D. Brougham, E. R. Dennett and S. T. Tan, "Non-Melanoma Skin Cancers in New Zealand-A Neglected Problem," The New Zealand Medical Journal, Vol. 123, No. 1325, 2010, pp. 59-65.

[6] H. Krueger, D. Williams, M. Chomiak and L. Trenaman, 
"The Economic Burden of Skin Cancer in Canada: Current and Projected," H. Krueger \& Associates Inc., Manitoba, 2010.

[7] K. Moore and L. J. Roberts, "Measurement of Lipid Peroxidation," Free Radical Research, Vol. 28, No. 6, 2008, pp. 659-671. doi:10.3109/10715769809065821

[8] D. Del Rio, A. J. Stewart and N. Pellegrini, "A Review of Recent Studies on Malondialdehyde as Toxic Molecule and Biological Marker of Oxidative Stress," Nutrition, Metabolism \& Cardiovascular Diseases, Vol. 15, No. 4, 2005, pp. 316-328. doi:10.1016/j.numecd.2005.05.003

[9] M. D. Pampanin, L. Camus, A. Gomiero, I. Marangon, E. Volpato and C. Nasci, "Susceptibility to Oxidative Stress of Muscles (Mytilus Galloprovincialis) in the Venice Lagoon (Italy)," Marine Pollution Bulletin, Vol. 50, No. 12, 2005, pp. 1548-1557. doi:10.1016/j.marpolbul.2005.06.023

[10] M. Bekerecioğlu, R. Aslan, S. Uğras, A. Kutluhan, R. Şekeroğlu, N. Akpolat and M. Karakök, "Malondialdehyde Levels in Serum of Patients with Skin Cancer," European Journal of Plastic Surgery, Vol. 21, No. 5, 1998, pp. 227229. doi:10.1007/s002380050076

[11] R. H. Chole, R. N. Patil, A. Basak, K. Palandurkar, R. Bhowate, "Estimation of Serum Malondialdehyde in Oral Cancer and Precancer and Its Association with Healthy Individuals, Gender, Alcohol, and Tobacco Abuse," Journal of Cancer Research Therapy, Vol. 6, No. 4, 2010, pp. 487-491. doi:10.4103/0973-1482.77106

[12] R. Ramya, S. Prakash and S. Sudha, "Assessment of Serum Malondialdehyde in Oral Squamous Cell Carcinoma Patients and Its Association with Tobacco Habits," Journal of Pharmaceutical and Biomedical Sciences (JPBMS), Vol. 10, No. 16, 2011, pp. 1-3.

[13] H. H. Ahmed, M. M. Hegazi, H. I. Abd-Alla, E. F. Eskander and M. S. Ellithey, "Antitumour and Antioxidant Activity of Some Red Sea Seaweeds in Ehrlich Ascites Carcinoma in Vivo," Z Naturforsch C, Vol. 66, No. 1-2, 2011, pp. 367-376. doi:10.5560/ZNC.2011.66c0367

[14] M. A. Choi, B. S. Kim and R. Yu, "Serum Antioxidative Vitamin Levels and Lipid Peroxidation in Gastric Carcinoma Patient," Cancer Letters, Vol. 136, No. 1, 1999, pp. 89-93. doi:10.1016/S0304-3835(98)00312-7

[15] A. Gönenç, Y. Özkan, M. Torun and B. Şimşek, "Plasma Malondialdehyde (MDA) Levels in Breast and Lung Cancer Patients," Journal of Clinical Pharmacy and Therapeutics, Vol. 26, No. 2, 2001, pp. 141-144. doi:10.1046/j.1365-2710.2001.00334.x

[16] F. McArdle, L. E. Rhodes, R. A. Parslew, G. L. Close, C. I. Jack, P. S. Friedmann and M. J. Jackson, "Effects of Oral Vitamin E and Beta-Carotene Supplementation on Ultraviolet Radiation-Induced Oxidative Stress in Human Skin," American Journal of Clinical Nutrition, Vol. 80, No. 5, 2004, pp. 1270-1275.
[17] S. Taysi, M. Koc, M. E. Büyükokuroğlu, K. Altınkaynak and Y. Nurişahin, "Melatonin Reduces Lipid Peroxidation and Nitric Oxide during Irradiation-Induced Oxidative Injury in the Rat Liver," Pineal Research, Vol. 34, No. 3, 2003, pp. 173-177. doi:10.1034/j.1600-079X.2003.00024.x

[18] K.-J. Hyeyoung, "Inhibitory Effects of $\alpha$-and $\beta$-Carotene on Croton Oil-Induced or Enzymatic Lipid Peroxidation and Hydroperoxide Production in Mouse Skin Epidermis," International Journal of Biochemistry, Vol. 25, No. 6, 1993, pp. 911-915.

[19] M. Basu, A. Banerjee, U. K. Bhattacharya, A. Bishayee and M. Chatterjee, "Beta-Carotene Prolongs Survival, Decreases Lipid Peroxidation and Enhances Glutathione Status in Transplantable Murine Lymphoma," Phytomedicine, Vol. 7, No. 2, 2000, pp. 151-159.

doi:10.1016/S0944-7113(00)80088-4

[20] L. Patrick, "Toxic Metals and Antioxidants: Part II the Role of Antioxidants in Arsenic and Cadmium Toxicity," Alternative Medicine Review, Vol. 8, No. 2, 2003, pp. 106-128.

[21] W. E. Hardman, J. Munoz Jr. and I. L. Cameron, "Role of Lipid Peroxidation and Antioxidant Enzymes in Omega 3 Fatty Acids Induced Suppression of Breast Cancer Xenograft Growth in Mice," Cancer Cell International, Vol. 2, No. 10, 2002, pp. 1-9. doi:10.1186/1475-2867-2-10

[22] H. S. Black, "Photocarcinogenesis and Diet," Federation Proceedings, Vol. 46, No. 5, 1987, pp. 1901-1905.

[23] M. A. Fischer and H. S. Black, "Modification of Membrane Composition, Eicosanoid Metabolism, and Immunoresponsiveness by Dietary Omega-3 and Omega-6 Fatty Acid Sources, Modulators of Ultraviolet-Carcinogenesis," Photochemistry and Photobiology, Vol. 54, No. 3, 1991, pp. 381-387. doi:10.1111/j.1751-1097.1991.tb02031.x

[24] M. Qi, D. Z. Chen, K. Liu, et al., "n-6 Polyunsaturated Fatty Acids Increase Skin But Not Cervical Cancer in Human Papillomavirus 16 Transgenic Mice," Cancer Research, Vol. 62, No. 2, 2002, pp. 433-436.

[25] B. S. Mackie, L. E. Mackie, L. D. Curtin and D. J. Bourne, "Melanoma and Dietary Lipids," Nutrition Cancer, Vol. 9, No. 4, 1987, pp. 219-226. doi: $10.1080 / 01635588709513930$

[26] R. M. Dam, Z. Huang, E. Giovannucci, E. B. Rimm, D. J. Hunter, G. A. Colditz, M. J. Stampfer and W. C. Willett, "Diet and Basal Cell Carcinoma of the Skin in a Prospective Cohort of Men," American Journal of Clinical Nutrition, Vol. 71, No. 1, 2000, pp. 135-141.

[27] C. Bain, A. Green, V. Siskind, J. Alexander and P. Harvey, "Diet and Melanoma," Vol. 3, No. 3, 2003, pp. 235-238. 